\title{
Investigation of LSF Structure Effect on Economy and Sustainable Housing in Iran. Case Study: $50 \mathrm{~m}^{2}$ Units
}

\author{
Davod Baradaran Tavakoli ${ }^{1}$, Negin Bareshadat ${ }^{1}$, Maryam Tafrishi $^{2}$ \& Ehsan Abbaspour ${ }^{1}$ \\ ${ }^{1}$ Architecture, Art and Architecture Faculty Branch, Islamic Azad University, Mashhad, Iran \\ ${ }^{2}$ Department of Art and Architecture, Shiraz Branch, Islamic Azad University, Fars, Iran \\ Correspondence: Davod Baradaran Tavakoli, Architecture, Art and Architecture Faculty branch, Islamic Azad \\ University, Mashhad, Iran. Tel: 98-930-470-1725. E-mail: davoodbaradaran@mshdiau.ac.ir
}

Received: April 9, 2017

Accepted: April 18, 2017

Online Published: June 20, 2017

doi:10.5539/res.v9n3p30

URL: http://doi.org/10.5539/res.v9n3p30

\begin{abstract}
Housing is an important element in government's broad social agenda. This element overlaps employment, health, education, crime and many other aspects of life. We can say housing is stable, when everyone has access to a minimum house, social cohesion promotes and people's lives improve toward self-reliance. On the other hand, designing stable buildings is aimed to reduce its damage on environment, energy resources and nature that requires spending to build housing, however, due to high cost of housing, poor sectors of society cannot buy house, while government has to provide house for all sectors in society. Assuming that LSF structures promote stability, this study is aimed to structural search to build urban buildings, which is responsive to sustainable architecture and can be justified economically. This study is analytical and based on library studies and comparative analogy tries to answer questions such as: how to use LSF structure in designing buildings in order to reduce their cost, and whether these structures is affordable across the country based on variety of building regulations in cities. In this regard, in order to examine LSF technology in construction and comparing it with conventional construction methods, we investigate and calculate 50 square meters one-bedroom apartments. Our conclusion indicates that using this technology in addition to positive response to sustainable architecture, increases the ability to buy a home, as well as strength and durability of these structures compared to conventional constructions in different environmental conditions and earthquake.
\end{abstract}

Keywords: structural LSF, stability, economy, housing

\section{Introduction}

Architectural design as a solution that aims to create a safe shelter against natural hazards has attracted people's attention since the beginning of history (Mahmoudi, 2008). There are different views in the field of stable housing, each of which are subject to certain parameters in design. Most of them are related to different construction practices, economic, social and technical housing issues. Sustainable development in a country will be achieved when this procedure becomes developments mainstream (Edwards \& Torrent, 2015). On one hand, after Human Rights Universal Declaration approval in 1948, the right to have an adequate house has been introduced as one of the components of "good living standards". Since then, all governments have imposed certain rules in housing sector, and established housing ministries or included housing department in other ministries in order to allocate funds and formulate policies, regulations of plans and special projects in housing sector. Among different ways of living, living in complex has a special place in society. Their primary use for rental plans to achieve greater density in minor areas is a requirement for access to more affordable housing (Vntlyng, 2015). Recently, price has become a precondition for manufacturers. Ascending growth of average house price has led to affordability crisis in buying a house, thus many potential buyers are excluded from the possibility of shopping in market. This, along with increased national debts and trade imbalances made the customers to caution about costs. Like government, owners must learn to live within their budget limit. Therefore, average cost of house should be balanced and also average area should be reduced (Vntlyng, 2015). Experience has shown that unusual growth of housing prices especially in large cities and not paying attention to this problem will be followed with numerous problems in cultural, social, economic and political aspects. Expansion of marginalization is one of these problems. 
In September 2000, the UN General Assembly announced its eight main objectives, which are called the Millennium Development Goals. In particular, one of the targets, which is called MDG (goal 7), has been established in order to improve the quality of life of at least 100 million dwellers by 2020 (Choguill, 2007). According to last census, the number of slum dwellers across the world is slightly less than 1 billion, that in most optimistic case and under full supervision of UN, $90 \%$ of these people settle in places that are very crowded, unsafe, makeshift, unsanitary and are likely to remain illegal until years after 2020, and consequences of Millennium Development Goals will be operated (Choguill, 2007). Hence, the issue of providing affordable, sustainable and decent housing for the low-income strata is considered as one of the emergent priorities of many governments throughout the world (Mahdavinejad, 2011).

Marginalization phenomenon is one of the causes of urban system instability-particularly in developing countries-and is an informal settlement market. However, this settlement shows poverty (indicates shortcomings and failures of government policies and formal housing market). So resolving this problem requires policy making and proceedings to provide stable affordable housing for low-income people. This study is aimed to provide a condition for all people to have an acceptable housing, thereby social cohesion, improvement and self-reliance in the field of sustainability increases. According to the fact that LSF helps to generate more affordable and more stable houses, thus in this study, this structure is investigated as a solution to meet the needs of low-income people, who require stable and affordable housing, in accordance with economic, social, and environmental approaches.
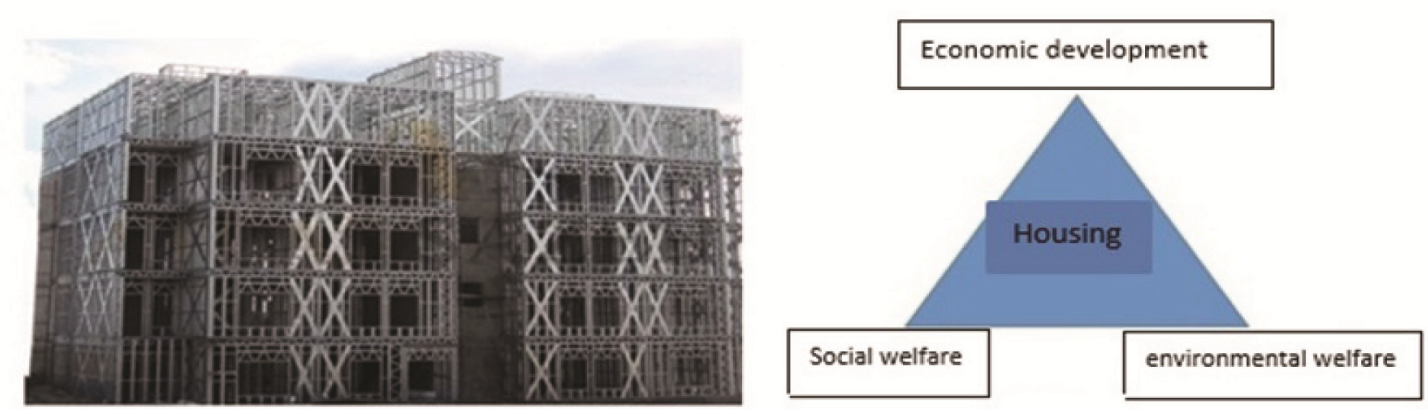

Figure 1. Using LSF structure in construction and importance of housing in creating stable communities

\section{Research Method}

This research process is combined, so that its foundation is based on an analytical method, but relying on library studies and using comparative method help us to respond to research questions that constitute foundation of expression, analysis, description, interpretation of contents.

\subsection{The Discussed Sample in This Study}

The examined samples in this study are one-bedroom apartments, located in four climates of Iran, including Gorgan, Sari (temperate and humid climate), Yazd, Isfahan (hot and dry climate), Tabriz, Ardabil (cold mountainous climate), Bushehr and Abadan (hot and humid climate) (Moradi, 2011).

\section{Theoretical Foundations}

\subsection{Urban and Construction Developments}

In 1393 we experienced the unprecedented downturn in housing sector that this recession was due to sales stagnating severity caused by costs anti-inflationary policy executed by government, which led to unexpected recession in housing market. Consequently, we experienced $50 \%$ reduction in construction and $70 \%$ reduction of investment in construction and apartment building sector that led to accumulation of built apartments. In addition, municipalities approved that construction license fees must increase $25 \%$ to $37 \%$ and it has caused a sharp rise in construction prices and sharp growth of housing prices in construction deterrence.

Government is responsible to resolve housing problem in the society. Government support in 1393 with mortgage payment and loan limit enhancement partly caused a boom in 50 to 80 meters small units, whereby more deals with these specifications occure in Tehran and country. According to Article 30 of the Fourth Development Plan, government is obliged to pay financial subsidies to building projects suppliers. Now, lending 
to low-income groups of society is very common in Iran, since top deciles of population can always provide their required housing, but middle deciles of population require government support to increase their purchase power.

\subsection{Lightweight Steel Framing (LSF)}

The basic and deep impact of structures principles and concepts in architecture, complete and accurate understanding of these principles in order to incorporate structural concepts with architectural design criteria for architects and construction engineers is necessary (Mario, 2012). Lightweight steel structure, which is briefly called LSF is one of the new construction systems and is used for buildings with limited floors up to 5 floors and is one of the civil engineers' approved systems in developed and modern countries. This structure is composed of rolled steel plates to provide stability, plates and plaster board as internal and external components. This system has the capability to be combined with other structural systems. Using this system reduces structural weight up to $50 \%$ and it is the greatest privilege against earthquake. In most cases, this system is implemented with light ceiling and as a case with other types of ceiling. Other part of the building are also implemented using cold-rolled profiles and is applicable with different types of facades such as stone, brick facade, PVC façade, wood or aluminum, paints, and ceramics and its inside like usual walls has the capability to use paint, wallpaper, etc. on plaster panels. The inside space of wall is filled with acoustic and thermal insulation (Heydari, 2013). Perhaps it can be said that this construction systems has been implemented, planned, and designed due to building industry needs in developed countries or to respond to goals such as industrial production of construction, economic construction, environmental considerations and sustainable development in construction industrial activities (Falah, 2012).

\subsection{Benefits of LSF Structures}

Recyclability of materials - easy transportation-having energy consumption standards-high quality connectivity-lightness and thus reduction of earthquake on structure-high and uniform quality of final product-high performance speed-high resistance and durability against adverse environmental conditions - facilitation of electrical and mechanical implementation- cultural adaptation of structure indoor and façade with traditional buildings - good acoustic performance- requiring low workshop space and more safety in the workshop-having anti-fire standards and regulations- land use and construction on lands with shoddy soil (Heydari, 2013).

\subsection{Stability}

The application of stability concepts and sustainable development goals to reduce energy waste and environment pollution in architecture has developed "stable architecture" subject. In this type of architecture, not only the construction is adapted with its climatic conditions, but also establishes a reciprocal relationship with it. So, according to Richard Rogers, "buildings are like birds that sheath their plumage in winter and adapt themselves to new conditions, and adjust their metabolism accordingly" (Mahmoud, 2014).

\subsection{Sustainable Housing}

The principle of sustainable housing is to give comfort and safety in human lives. The application of this principle occurs directly and indirectly recognized by the owner or not. The principles applied in sustainable housing, including concern for people by ensuring that they live in a healthy, productive and in harmony with nature (Nazirah, 2005). This principle needs to give priority to the interests of future generations without compromising the needs of the present generation (Abd \& Arkam, 2013).

\section{Cost of Houses, Which Are Built with LSF System}

In (Table 1) approximate amount of materials that are needed in LSF to build residential units with an area of 50 square meters, are indicated. 
Table 1. Approximate amount of required materials for residential apartment units with an area of 50 square meters in LSF structures method

\begin{tabular}{cccc}
\hline Amount & Type of material & Amount & Type of material \\
\hline 70-100 Square meters & Roofix & $1600-1750 \mathrm{Kg}$ & Metal sheet \\
$9-14$ Square meters & Window & $400-500 \mathrm{Kg}$ & Reinforcing load \\
3 & Door & 4 & Door form \\
2 units & Health network & 1 & Gate \\
5 4/4-ton & Cement & $13-18 \mathrm{M}$ & Concrete \\
$225-268 \mathrm{M}$ & Plaster board & 4 units & Faucet \\
$5500-5700$ & Board-Sheet pitch & $150-190$ Square meters & Cement boards \\
$100-140$ Square meters & Insulator & 26 & Switches and Sockets \\
\hline
\end{tabular}

Source: authors.

\section{Analysis}

Now, considering this amount of material, construction basis and total cost of residential houses with an area of 50 square meters in Gorgan, Sari, Yazd, Isfahan, Tabriz, Ardebil, Boushehr, Abadan and Tehran with LSF method is presented in (Table 2). It should be noted that in LSF method, in addition to effective coefficients, skilled force coefficient will also be considered and also it has less overhead cost compared to other methods. The effective coefficient includes: overhead factor-workshop mobilization factor-regional coefficient - coefficient of floors- height factor - contractor's suggested factor and adjustment factor. Taxes and charges include: charges, taxes and construction optimal value which are considered in effective coefficient calculations.

Table 2. Total cost of all residential apartment units with LSF structure method

\begin{tabular}{ccccc}
\hline Climate & Case examples & $\begin{array}{c}\text { The base cost for per square } \\
\text { meter (one thousand Tomans) }\end{array}$ & $\begin{array}{c}\text { Effective } \\
\text { coefficient }\end{array}$ & $\begin{array}{c}\text { Cost per square meter(one } \\
\text { thousand Tomans) }\end{array}$ \\
\hline \multirow{2}{*}{ Mild and humid } & Tehran & $460-535$ & $1 / 37$ & $632-733$ \\
& Gorgan & $460-535$ & $1 / 44$ & $664-770$ \\
Warm and dry & Sari & $460-535$ & $1 / 46$ & $672-781$ \\
Yazd & Isfahan & $460-535$ & $1 / 52$ & $700-815$ \\
Mountainous & Tabriz & $460-535$ & $1 / 33$ & $612-712$ \\
& Ardebil & $460-535$ & $1 / 39$ & $640-744$ \\
Warm and wet & Boushehr & $460-535$ & $1 / 56$ & $718-835$ \\
& Abadan & $460-535$ & $1 / 75$ & $805-935$ \\
\hline
\end{tabular}

Source: authors.

Now, in order to compare, analyze and interpret data we require Iran conventional construction data (Table 3). By applying effective coefficients of planning organization, construction costs are predicted in conventional non-mass construction method. In addition, the costs of mass construction per square meter are provided for mentioned cities in four climate types (Table 4). 
Table 3. Estimated cost of non-mass construction in conventional methods

\begin{tabular}{ccccc}
\hline Climate & Case examples & $\begin{array}{c}\text { The base cost for per square } \\
\text { meter (one thousand } \\
\text { Tomans) }\end{array}$ & $\begin{array}{c}\text { Effective } \\
\text { coefficient }\end{array}$ & $\begin{array}{c}\text { Cost per square meter(one } \\
\text { thousand Tomans) }\end{array}$ \\
\hline \multirow{2}{*}{ Mild and humid } & Tehran & $656-715$ & $1 / 7$ & $1115-1215$ \\
Warm and dry & Gorgan & $656-715$ & $1 / 57$ & $1030-1122$ \\
Cold and & Yari & $656-715$ & $1 / 59$ & $1035-1137$ \\
Mountainous & Isfahan & $656-715$ & $1 / 72$ & $1128-1230$ \\
Warm and wet & Tabriz & $656-715$ & $1 / 7$ & $1115-1215$ \\
& Ardebil & $656-715$ & $1 / 75$ & $1148-1251$ \\
& Boushehr & $656-715$ & $1 / 82$ & $1194-1300$ \\
& Abadan & $656-715$ & $1 / 82$ & $1194-1300$ \\
\hline
\end{tabular}

Table 4. Estimated cost of mass construction in conventional methods

\begin{tabular}{ccccc}
\hline Climate & Case examples & $\begin{array}{c}\text { The base cost for per square } \\
\text { meter (one thousand Tomans) }\end{array}$ & $\begin{array}{c}\text { Effective } \\
\text { coefficient }\end{array}$ & $\begin{array}{c}\text { Cost per square meter(one } \\
\text { thousand Tomans) }\end{array}$ \\
\hline \multirow{3}{*}{ Mild and humid } & Tehran & $656-715$ & $1 / 45$ & $951-1036$ \\
& Gorgan & $656-715$ & $1 / 48$ & $970-1058$ \\
Warm and dry & Sari & $656-715$ & $1 / 49$ & $977-1065$ \\
Cold and & Yazd & $656-715$ & $1 / 52$ & $997-1087$ \\
Mountainous & Isfahan & $656-715$ & $1 / 47$ & $964-1051$ \\
& Tabriz & $656-715$ & $1 / 42$ & $931-1015$ \\
Warm and wet & Ardebil & $656-715$ & $1 / 56$ & $1023-1115$ \\
& Boushehr & $656-715$ & $1 / 65$ & $1082-1180$ \\
\hline
\end{tabular}

According to the findings and above tables data regarding total cost per square meter of housing units based on conventional methods (mass and non-mass construction) and also LSF system, we can obtain the results by comparing total costs per square meter.

Table 5. Comparison of total cost per square meter of residential apartments in conventional method (mass and non-mass construction) and LSF method

\begin{tabular}{|c|c|c|c|c|}
\hline Climate & Case examples & $\begin{array}{l}\text { Total cost for per square meter } \\
\text { in mass construction (one } \\
\text { thousand Tomans) }\end{array}$ & $\begin{array}{l}\text { Total cost for per square } \\
\text { meter in non-mass } \\
\text { construction }\end{array}$ & $\begin{array}{l}\text { Total cost for per square } \\
\text { meter in LSF method(one } \\
\text { thousand Tomans) }\end{array}$ \\
\hline \multirow{3}{*}{ Mild and humid } & Tehran & $951-1036$ & $1115-1215$ & $632-733$ \\
\hline & Gorgan & $970-1058$ & $1030-1122$ & $664-770$ \\
\hline & Sari & $977-1065$ & $1035-1137$ & $672-781$ \\
\hline \multirow{2}{*}{ Warm and dry } & Yazd & $997-1087$ & $1128-1230$ & $700-815$ \\
\hline & Isfahan & $964-1051$ & $1115-1215$ & $612-712$ \\
\hline \multirow{2}{*}{$\begin{array}{c}\text { Cold and } \\
\text { Mountainous }\end{array}$} & Tabriz & $931-1015$ & $1148-1251$ & $640-744$ \\
\hline & Ardebil & $1023-1115$ & $1194-1300$ & $718-835$ \\
\hline \multirow{2}{*}{ Warm and wet } & Boushehr & $1082-1180$ & $1194-1300$ & $805-935$ \\
\hline & Abadan & $1062-1158$ & $1180-1287$ & $782-910$ \\
\hline
\end{tabular}

Source: authors. 
In LSF method, in addition to achieving higher quality, reducing construction weight (better resistance against earthquakes) and rapid construction (reduction of workshops and overhead coefficients) and significant reduction of materials consumption (for example, reduction of consumed rebar by $30 \%$ compared to conventional methods) and other benefits, normal construction costs reduce.

\section{Conclusion}

Studies show that using LSF technology in construction industry is affordable and reduces total cost of houses, it reveals a new horizon of economy in construction industry, thereby it leads to saving materials used during construction, using less materials based on building area because of design features and type of materials, rapid construction, focused design activities, production and monitoring the construction (reduction of plan overhead costs), low maintenance and repair costs (interchangeable components) and cost-effectiveness in all-weather climates of Iran. Since Iran is a developing country and it is accompanied by population growth, as well as hardly provided economic, social and environmental conditions for all people to have a house, thus using this new method in construction leads to less payment, strength and stability of housing for low-income people and provides a bed for progress of country and development of housing supply targets.

\section{References}

Abd, R., \& Arkam Che Munaaim, M. (2013). Sustainable House in Iran's Desert.

Choguill, C. L. (2007). The search for policies to support sustainable housing. Habitat International, 31, 143-149. https://doi.org/10.1016/j.habitatint.2006.12.001

Edwards, B., \& Torrent, D. (2015). Sustainable housing. Publications Parham Role, 1, 15.

Falah, M. et al. (2012). Studying the light steel building system (1st ed.). Tehran: Building and Housing Research Center.

Heydari, A. (2013). Light steel frame 1st. In Forums Civil Engineering and Architecture.

Mahdavinejad, M. et al. (2011). Role of LSF technology in economic housing for urban sustainability, case of Iran. Procedia Engineering, 21, 2-7. https://doi.org/10.1016/j.proeng.2011.11.1980

Mahmoud, M. (2014). Housing development compatible with sustainable development (p. 133). Tehran: Tehran University Press.

Mahmoudi, M., Simchi, A., Imani, M., Milani, A. S., \& Stroeve, P. (2008). Vivo MRI Detection of Gliomas by Chlorotoxin-Conjugated Superparamagnetic Nanoprobes (Vol. 112, pp. 14470-14481).

Mario, S. (2012). Architectural structures (G. Mahmoud, Trans.). Tehran University Press.

Moradi, S. (2011). Set the environmental conditions (p. 11). Press Shahidi.

Nazirah, Z. A. P. (2005). Delivering sustainability through value management: The concept and performance overview. Engineering Construction and Architectural Management, 168-180.

Vntlyng, J. (2015). Based on life-style housing design (G. Habib, Trans.). Publications Ktabkdh deficit.

\section{Copyrights}

Copyright for this article is retained by the author(s), with first publication rights granted to the journal.

This is an open-access article distributed under the terms and conditions of the Creative Commons Attribution license (http://creativecommons.org/licenses/by/4.0/). 